\title{
Replication error phenotype, clinicopathological variables, and patient outcome in Dukes' B stage II $(\mathrm{T} 3, \mathrm{~N} 0, \mathrm{M} 0)$ colorectal cancer
} B Curran, K Lenehan, H Mulcahy, O Tighe, M A Bennett, E W Kay, D P O’Donoghue,
M Leader, D T Croke
Alterations include the activation of oncogenes ${ }^{5}$ and the inactivation, by a combination of mutation and deletion, of tumour suppressor genes. ${ }^{1}$ More recently, the study of hereditary non-polyposis colorectal cancer (HNPCC) has helped to identify a new class of tumour susceptibility gene, namely the mismatch repair gene. ${ }^{6}$ Inherited mutation in one of a number of genes identified to date (including hMSH2, hMLH1, hPMS1, hPMS2) results in defective repair of mismatched bases and leads to a replication error positive (RER+) phenotype and microsatellite instability in HNPCC individuals. ${ }^{711}$ These patients tend to develop right sided, predominantly diploid, and often poorly differentiated cancers at an early age. ${ }^{12}$

Although microsatellite instability was initially associated with HNPCC, it is not limited to such tumours, but is also found in $7-20 \%$ of sporadic colorectal cancers. ${ }^{11}{ }^{13-17}$ However, a number of important genotypic and phenotypic differences have been found between inherited and sporadic RER+ tumours. Patients with inherited RER+ tumours tend to have germline mutations within the currently known DNA mismatch repair genes, whereas sporadic RER+ tumours tend not to have germline mismatch repair gene alterations and rarely harbour such mutations in their tumours. ${ }^{18} 19$ In addition, a positive family history of colorectal cancer is no more prevalent in patients with sporadic RER+ tumours than those with RER- tumours. ${ }^{16}$ This indicates that additional, as yet unidentified, genetic events may affect replication fidelity in sporadic cancer, ${ }^{19}$ with an alternative pathway leading to an RER+ phenotype in these cases. ${ }^{20}$ Furthermore, these differences also suggest that the clinical features associated with RER+ sporadic cancers may be different to those associated with RER+ HNPCC cancers.

Only a small number of studies have analysed microsatellite instability in relation to the clinical, pathological, or molecular features of sporadic colorectal cancer and all have included a mixture of early and advanced cases. $^{13}{ }^{19}$ However, the anatomical extent of sporadic colorectal cancer is closely related to long term survival, ${ }^{21}$ cellular differentiation, ${ }^{22}$ and the occurrence of genetic alterations. Thus, studies which include both early and

Abbreviations used in this paper: HNPCC, hereditary non-polyposis colorectal cancer; RER, replication error. \begin{abstract}
accepted model of a stepwise progression from normal mucosa to metastatic colorectal cancer via adenomatous polyp formation and invasive cancer, associated with accumulating mutations in a number of growth regulating genes. ${ }^{1-4}$

Keywords: colon cancer; replication error phenotype; microsatellite instability; c-Ki-ras mutation; p53 expression; c-erbB-2

Sporadic colorectal cancer serves as an impo molecular pathogenesis of this disease has been
\end{abstract}


advanced tumours without adequate correction for tumour stage are likely to have biases inherent in them. The aim of our study was to examine the relation between microsatellite instability and other genetic events, clinical features, and long term survival in patients with colorectal cancer. However, to eliminate the confounding effect of tumour stage on microsatellite instability, we only included patients who underwent potentially curative surgery for cancers which had penetrated beyond the bowel wall but which had not breached the peritoneal surface, spread to other organs, or metastasised to lymph nodes or distant sites at the time of operation $(\mathrm{T} 3, \mathrm{~N} 0, \mathrm{M} 0)$.

\section{Methods}

PATIENTS

A series of 159 consecutive patients with T3,N0,M0 (Dukes' B, stage II) colorectal cancer (median age 69.7 years, range 40.7-90.0; 77 women, 82 men) admitted to St Vincent's Hospital, Dublin, between 1983 and 1989 formed the basis of the study. Clinical data were extracted from a prospective computer database containing details of all colorectal cancer patients admitted since 1983. No study patient received preoperative or postoperative chemotherapy or radiotherapy. Follow up for this study ended in February 1996, and median follow up was 7.9 years (mean 7.9 years; range 5.0-11.5) for patients alive at the completion of follow up. The pathologist and technical investigators were blinded to all clinical details and patient outcome. Histological sections were

Table 1 Clinical and pathological features of 159 patients with T3,NO,MO colorectal cancer stratified by replication error (RER) status

\begin{tabular}{llll}
\hline & $\begin{array}{l}\text { RER- cancers } \\
(n=137)\end{array}$ & $\begin{array}{l}\text { RER+ cancers } \\
(n=22)\end{array}$ & $p$ Value \\
\hline $\begin{array}{l}\text { Age (y) median (IQ range) } \\
\text { Sex }\end{array}$ & $70(60-75)$ & $67(64-73)$ & $0.89^{\star}$ \\
$\quad$ Male & $69(50 \%)$ & $13(59 \%)$ & $0.48 \dagger$ \\
$\quad \begin{array}{l}\text { Female } \\
\text { Tumour site }\end{array}$ & $68(50 \%)$ & $9(41 \%)$ & \\
$\quad$ Right colon & $44(29 \%)$ & $13(59 \%)$ & $0.006 \dagger$ \\
$\quad$ Left colon/rectum & $97(71 \%)$ & $9(41 \%)$ & $0.01^{\star}$ \\
$\quad$ Tumour size (cm) median (IQ range) & $5.0(3.5-6.0)$ & $6.0(5.0-8.0)$ & $0.0008 \ddagger$ \\
$\quad \begin{array}{l}\text { Tumour differentiation } \\
\quad \text { Mell }\end{array}$ & $7(5 \%)$ & 0 & \\
$\quad 123(90 \%)$ & $16(73 \%)$ & \\
$\quad$ Poor & $7(5 \%)$ & $6(27 \%)$ & \\
\hline
\end{tabular}

*Wilcoxon's rank sum test.

$\dagger \chi^{2}$ test.

$\ddagger \chi^{2}$ test for trend.

Table 2 Molecular and immunohistochemical features of 159 patients with T3,NO,MO colorectal cancer stratified by replication error (RER) status

\begin{tabular}{|c|c|c|c|c|}
\hline & $\begin{array}{l}\text { RER- cancers } \\
(n=137)\end{array}$ & $\begin{array}{l}R E R+\text { cancers } \\
(n=22)\end{array}$ & OR $(95 \% C I)$ & $p$ Value \\
\hline \multicolumn{5}{|c|}{$\overline{\text { K-ras mutation }}{ }^{\star}$} \\
\hline Absent & $90(69 \%)$ & $19(86 \%)$ & \multirow[t]{2}{*}{$0.40(0.08-1.37)$} & \multirow[t]{2}{*}{$0.13 \dagger$} \\
\hline Present & $40(31 \%)$ & $3(14 \%)$ & & \\
\hline \multicolumn{5}{|c|}{ p53 immunostaining } \\
\hline Absent & $77(56 \%)$ & $10(46 \%)$ & \multirow[t]{2}{*}{$1.52(0.57-4.17)$} & \multirow[t]{2}{*}{$0.48 \ddagger$} \\
\hline Present & $60(44 \%)$ & $12(55 \%)$ & & \\
\hline \multicolumn{5}{|c|}{ c-erbB-2 immunostaining ${ }^{\star}$} \\
\hline Absent & $85(66 \%)$ & $9(45 \%)$ & \multirow[t]{2}{*}{$2.38(0.85-6.95)$} & \multirow[t]{2}{*}{$0.11 \ddagger$} \\
\hline Present & $43(34 \%)$ & $11(55 \%)$ & & \\
\hline \multicolumn{5}{|c|}{ c-myc immunostaining ${ }^{\star}$} \\
\hline Absent & $53(42 \%)$ & $6(30 \%)$ & \multirow[t]{2}{*}{$1.60(0.19-1.81)$} & \multirow[t]{2}{*}{$0.46 \ddagger$} \\
\hline Present & $74(58 \%)$ & $14(70 \%)$ & & \\
\hline
\end{tabular}

*Information not available for all patients.

†Fisher's exact test.

$\neq \chi^{2}$ test.

$\mathrm{OR}$, odds ratio; CI, confidence interval. retrieved and evaluated to confirm tumour stage and tumour differentiation, and to select suitable formalin fixed, paraffin wax embedded tissue blocks for DNA extraction and immunohistochemistry. Tumour DNA was extracted from blocks containing at least $70 \%$ tumour cells and wild type DNA was obtained from blocks containing only normal tissue. DNA was extracted by a boiling/proteinase $\mathrm{K}$ method as described previously. ${ }^{23}$ The presence of c-Ki-ras activating mutations in these samples has been investigated previously by a polymerase chain reaction (PCR) based method. ${ }^{23}$

DETECTION OF MICROSATELLITE INSTABILITY Highly polymorphic microsatellite markers linked to four tumour suppressor gene loci were used to detect microsatellite instability as allele mobility shifts. The microsatellite markers studied included D5S82 and D5S346 (chromosome 5q), TP53 (chromosome 17p), D18S474 and DCC1.1/1.2 (chromosome 18q), and D17S579, NM23, and D17S293 (chromosome 17q). Template DNA was amplified by PCR with primers specific for each marker using previously reported reagents and reaction conditions. ${ }^{24-29}$ PCR products were electrophoresed on standard DNA sequencing gels and visualised either by autoradiography (following incorporation of radiolabel during PCR) or by automated fluorescent detection (ALFexpress DNA Sequencer, Pharmacia, Sweden). Microsatellite instability was indicated by the presence of allelic shifts whereby one or more different alleles were present in tumour DNA as compared with the matched normal sample. A case was designated RER+ if at least two of the markers studied reproducibly exhibited allelic shifts. ${ }^{16}$

DETECTION OF p53 AND c-erbB-2 (p185her-2/neu)

EXPRESSION

Sections $(5 \mu \mathrm{m})$ were prepared for immunohistochemistry as described previously. ${ }^{23} 3031$ Cases displaying unequivocal strong nuclear staining with the NCL-p53-CM1 antibody (Novocastra, UK) were considered positive for p53. ${ }^{23}{ }^{32}$ Focal or diffuse c-erbB-2 staining with the NCL-CB11 antibody (Novocastra) was regarded as positive for c-erbB-2 expression. ${ }^{30}$ Intense nuclear staining with the primary monoclonal antibody OM-11-908 (Cambridge Research Biochemicals, UK) was scored as positivity for c-myc expression. ${ }^{33} 34$

STATISTICAL METHODS

Categorical data were compared with the $\chi^{2}$ test or Fisher's exact test as appropriate. Odds ratios and $95 \%$ confidence intervals were calculated with a correction factor of $0.5 .^{35}$ Non-parametric data were assessed with Wilcoxon's rank sum test. Kaplan-Meier survival curves were constructed with cancer related death as the end point. Differences in survival between groups were compared using the log rank test. Multivariate survival analyses were performed with the Cox proportional hazards model using the Statistical Package for the Social Sciences (SPSS, Illinois, USA). Model 
Table 3 Clinical, pathological, and molecular features of 22 patients with replication error (RER) positive T3,N0,MO colorectal cancers

\begin{tabular}{|c|c|c|c|c|c|c|c|c|c|c|}
\hline \multirow{2}{*}{$\begin{array}{l}\text { Study } \\
\text { number }\end{array}$} & \multirow[b]{2}{*}{ Age } & \multirow[b]{2}{*}{$\operatorname{Sex}$} & \multirow[b]{2}{*}{ Tumour site } & \multirow{2}{*}{$\begin{array}{l}\text { Tumour } \\
\text { size }(\mathrm{cm})\end{array}$} & \multirow{2}{*}{$\begin{array}{l}\text { Tumour } \\
\text { grade }\end{array}$} & \multirow{2}{*}{$\begin{array}{l}\text { Number of } \\
R E R+\text { loci }\end{array}$} & \multirow{2}{*}{$\begin{array}{l}\text { K-ras } \\
\text { mutation }\end{array}$} & \multicolumn{3}{|c|}{ Gene expression } \\
\hline & & & & & & & & $p 53$ & $c-e r b B-2$ & $c-m y c$ \\
\hline 6 & 69.6 & Male & Caecum & 3.0 & Moderate & 2 & - & + & NA & NA \\
\hline 16 & 49.9 & Male & Transverse colon & 8.0 & Poor & 2 & - & - & NA & NA \\
\hline 30 & 71.9 & Male & Sigmoid colon & 6.0 & Moderate & 3 & - & - & - & + \\
\hline 34 & 77.2 & Male & Transverse colon & 8.0 & Moderate & 2 & - & - & + & + \\
\hline 36 & 84.1 & Male & Caecum & NA & Moderate & 4 & - & + & + & + \\
\hline 49 & 69.6 & Female & Ascending colon & 7.0 & Moderate & 2 & - & + & + & + \\
\hline 50 & 82.8 & Female & Caecum & 5.0 & Poor & 2 & - & + & + & - \\
\hline 51 & 72.0 & Male & Rectum & 6.0 & Moderate & 2 & - & - & + & + \\
\hline 52 & 64.5 & Female & Sigmoid colon & 3.0 & Moderate & 2 & + & + & + & + \\
\hline 53 & 64.8 & Female & Ascending colon & 8.0 & Poor & 3 & - & + & + & + \\
\hline 69 & 63.6 & Female & Rectum & 4.0 & Poor & 2 & - & + & + & + \\
\hline 73 & 73.2 & Male & Transverse colon & 8.0 & Poor & 4 & - & - & + & + \\
\hline 81 & 74.0 & Male & Sigmoid colon & 7.0 & Moderate & 2 & - & - & - & - \\
\hline 107 & 67.4 & Female & Ascending colon & 9.5 & Poor & 3 & - & + & - & + \\
\hline 115 & 59.0 & Male & Rectum & 11.0 & Moderate & 2 & - & - & + & - \\
\hline 129 & 54.2 & Female & Rectum & 7.0 & Moderate & 2 & + & + & - & - \\
\hline 135 & 51.5 & Female & Rectum & 6.0 & Moderate & 3 & - & + & - & - \\
\hline 138 & 74.9 & Female & Caecum & 5.0 & Moderate & 3 & + & - & - & + \\
\hline 139 & 67.1 & Male & Ascending colon & 3.0 & Moderate & 3 & - & + & + & - \\
\hline 143 & 73.1 & Male & Caecum & 6.0 & Moderate & 3 & - & - & - & + \\
\hline 148 & 64.4 & Male & Rectum & 6.0 & Moderate & 2 & - & - & - & + \\
\hline 153 & 62.7 & Male & Ascending colon & 5.0 & Moderate & 2 & - & + & - & + \\
\hline
\end{tabular}

NA, data not available.

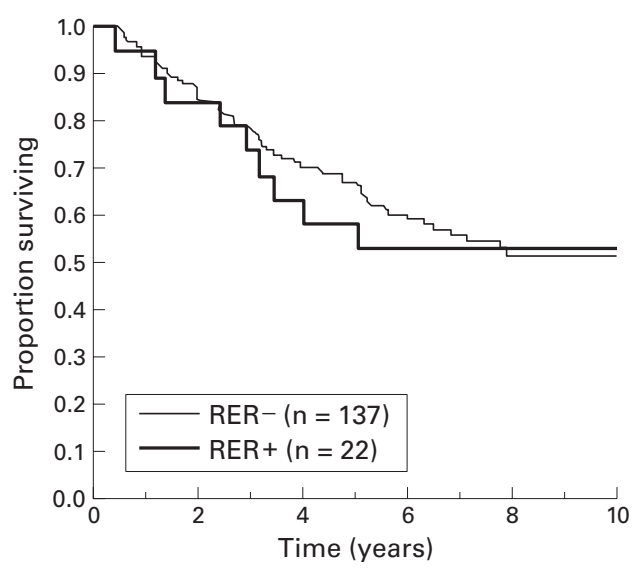

Figure 1 Survival of 159 patients with T3,NO,MO colorectal cancer stratified by replication error (RER) status.

assumptions were checked by observing constant vertical differences between plots of the logarithm of the integrated hazard function for each variable. ${ }^{36}$ Probability values less than 0.05 were considered significant in all analyses.

\section{Results}

Of the 159 colorectal cancers studied, 22 (14\%) were found to be RER+ while 137 (86\%) were RER - for two or more loci. The median age of patients with RER+ tumours was 67 years compared with 70 years for those with RER- cancers ( $p=0.89$; table 1$)$. RER+ tumours were found more commonly located in the right colon $(\mathrm{p}=0.006)$, tended to be larger than RER - tumours $(\mathrm{p}=0.01)$, and were more often poorly differentiated than RERcancers $(p=0.0008)$. A number of DNA based and immunohistochemical assays were used to assess the relation between tumour RER status and other molecular features (table 2). No significant associations were seen between RER status and the presence of a mutant c-Ki-ras gene, or between RER status and p53, c-erbB-2, or c-myc gene expression. Table 3 lists the clinical, molecular, and immunohistochemical findings for the 22 RER+ cases.

Univariate survival analysis showed that outcome was similar in RER+ and RER- cases (log rank test, $\mathrm{p}=0.68$; fig 1 ). To allow for possible confounding factors, we entered RER status, patient age, tumour differentiation, tumour site, and tumour size into a multivariate survival analysis. This showed that the relative risk of death for patients with RER+ cancers was 0.95 that of patients with RERcancers (95\% confidence interval, 0.41-2.17; $\mathrm{p}=0.90)$.

\section{Discussion}

Tumour development is a multistage process, involving many changes in the nuclear material of the cell. These changes result in significant alterations in the cellular phenotype including the control of cell growth and division. Vogelstein and colleagues ${ }^{1}$ have outlined some of the genetic changes specific to colorectal tumour progression from adenoma to carcinoma including DNA hypomethylation, activation of oncogenes, and inactivation of tumour suppressor genes. The multistep nature of colorectal cancer progression involving some or all of the above genes is widely accepted. ${ }^{3437}$ However, there has been considerable speculation as to whether microsatellite instability reflected the presence of a fundamentally different pathway to malignancy, or if it merely represented a variation on a relatively consistent theme of oncogene activation and tumour suppressor gene loss. Based on an inverse association between microsatellite instability and the presence of c-Ki-ras and p53 mutations, Ionov and colleagues ${ }^{15}$ suggested that microsatellite instability might form the basis for an entirely new mechanism for carcinogenesis. Thibodeau and colleagues ${ }^{17}$ also showed a significant inverse relation between microsatellite instability and loss of heterozygosity at chromosomes 5q, 17p, and 18q. However, more recently, a considerable body of evidence has accumulated in the literature which 
suggests that microsatellite instability does indeed characterise a second parallel pathway to malignancy. ${ }^{38}$ Genomic instability has now been shown to give rise to genetic alterations in loci including TGF $\beta 1 \mathrm{RII}^{39}$ and IGFIIR. ${ }^{40}$ Indeed, a link has recently been reported between abnormal genomic imprinting and microsatellite instability in colon tumours. ${ }^{41}$

A study by Kim and colleagues ${ }^{42}$ showed that right sided RER+ tumours expressed lower levels of p53 product than RER- cases. However, these data appear to contradict the results of many other studies. Aaltonen and colleagues $^{13}$ found $\mathrm{c}-\mathrm{Ki}$-ras and APC gene mutations in a similar proportion of RER+ and RER - colorectal cancers, while Watatani and colleagues $^{43}$ and Ilyas and colleagues ${ }^{32}$ found that p53 gene mutation or overexpression was no more frequent in RER- than in RER+ colorectal cancers. Furthermore, although Konishi et al found that mutation of the APC, c-Ki-ras, and p53 genes occurred more frequently in HNPCC RER+ tumours than in sporadic RER+ tumours, they found no difference in the incidence of mutation in these genes between sporadic RER+ and RERtumours. ${ }^{19}$ Loss of heterozygosity at chromosomes $5 \mathrm{q}, 8 \mathrm{p}, 17 \mathrm{p}, 18 \mathrm{q}$, and $22 \mathrm{q}$ also occurred no more frequently in sporadic RER+ than in RER- tumours. ${ }^{19}$ Our data, indicating the fact that c-Ki-ras alterations and p53, c-erb, and c-myc protein overexpression occur with similar frequencies in sporadic RER+ and RERcancers agree with these latter studies. However, table 2 indicates that there may be a trend towards a lower rate of K-ras alterations in RER+ tumours and a higher rate of c-erbB-2 immunostaining in these cases. Thus, we cannot exclude the possibility of a type 2 error in these data.

It is clear that the presence of an RER+ genotype has either some influence on, or at least an association with, a number of clinical and pathological characteristics of sporadic tumours. In accordance with almost all previous studies, we found that RER+ tumours tended to be right sided and poorly differentiated. In addition, RER+ tumours within this anatomically homogeneous series of colorectal cancers tended to be larger than in the RERcases. The reason for this is unclear, although it is possible that the presence of an RER+ genotype may lead to enhanced growth characteristics without affecting the ability of a tumour to invade or metastasise to lymph nodes or distant organs.

The stage of the primary tumour at the time of initial operation is known to influence greatly the long term survival of colorectal cancer patients. Thus, we specifically omitted all but T3,N0,M0 (stage II) cases in an attempt to minimise any survival bias caused by variable anatomical staging of RER+ and RER- cases. In addition, we studied a series of patients with adequate follow up times to reduce the possibility of missing late, but potentially important, survival effects induced by RER status. Our 10 year survival analysis showed no difference between RER+ and RER- stage II cases. Even when entered into a multivariate analysis along with other possibly important confounding variables such as tumour grade, survival was almost identical in both RER+ and RER- cases. These results initially appear to be at variance with some earlier studies, but close examination shows that this is not the case. Lothe et al, ${ }^{16}$ in a series of 238 patients with colorectal cancer of variable stages, found that patients with RER+ tumours had a significantly better seven year survival rate than those with RER- cancers. However, this association between RER status and long term survival disappeared when the data were corrected for tumour stage in a multivariate analysis. Thibodeau and colleagues ${ }^{17}$ also found a positive association between the presence of microsatellite instability and outcome in the first four years after surgery, but no significant association in stage II or III cancers. It is probable that further studies examining a consecutive series of colorectal cancers of different tumour stages and assessing additional genetic alterations, will clarify the association between RER status, tumour progression, and clinical outcome. However, the above results suggest that if RER status does indeed have an important bearing on long term survival, then the effect is likely to be seen more prominently either in cases confined to the bowel wall or in those which have already metastasised to lymph nodes or to distant organs at the time of operation.

We gratefully acknowledge financial support from the Health Research Board of Ireland and from the Research Committee of the Royal College of Surgeons in Ireland.

1 Vogelstein B, Fearon ER, Hamilton SR, et al. Genetic alterations during colorectal tumour development. $\mathrm{N} \mathrm{Engl} \mathrm{F} \mathrm{Med}$ 1988;319:525-31.

2 Fearon ER, Vogelstein B. A genetic model for colorectal tumorigenesis. Cell 1990;61:759-67.

3 Aaltonen L. The multistep nature of colon carcinogenesis. Cytokines Cell Mol Ther 1996;2:111-14.

Tomlinson I, Ilyas M, Novelli M. Molecular genetics of colon cancer. Cancer Metastasis Rev 1997;16:67-79.

colon cancer. Cancer Metastasis Rev 1997;16:67-79.
5 Bos JL, Fearon ER, Hamilton SR, et al. Prevalence of ras Bos JL, Fearon ER, Hamilton SR, et al. Prevalence of ras
gene mutations in human colorectal cancers. Nature 1987; 327:293-7.

6 Peltomaki P, Aaltonen LA, Sistonen P, et al. Genetic mapping of a locus predisposing to colorectal cancer. Science 1993;260:810-12.

7 Fishel R, Lescoe MK, Rao MRS, et al. The human mutator gene homolog MSH2 and its association with hereditary nonpolyposis colorectal cancer. Cell 1993;75:1027-38.

8 Bronner CE, Baker SM, Morrison PT, et al. Mutation in the DNA mismatch repair gene homologue hMLH1 is associated with hereditary non-polyposis colon cancer. Nature 1994;368:258-61.

9 Nicolaides NC, Papadopoulos N, Lui B, et al. Mutations of two PMS homologues in hereditary nonpolyposis colon cancer. Nature 1994;371:75-80.

10 Meuth M. Patterns of mutation in cancer cells. Cancer Surv 1996;28:33-46.

11 Peltomaki $\mathrm{P}$, de la Chapelle A. Mutations predisposing to hereditary nonpolyposis colorectal cancer. Adv Cancer Res 1997;71:93-119.

12 Lynch HT, Smyrk TC, Watson P, et al. Genetics, natural history, tumor spectrum and pathology of hereditary nonpolyposis colorectal cancer: an updated review. Gastroenterology 1993;104:1535-49.

13 Aaltonen L, Peltomaki P, Leach FS, et al. Clues to the pathogenesis of familial colorectal cancer. Science 1993; 260:812-16

14 Aaltonen L, Peltomaki P, Mecklin JP, et al. Replication errors in benign and malignant tumours from hereditary
non-polyposis colorectal cancer patients. Cancer Res 1994; 54:1645-8.

15 Ionov Y, Peinado MA, Malkhosyan S, et al. Ubiquitous somatic mutations in simple repeated sequences reveals a new mechanism for colorectal carcinogenesis. Nature 1993;363:558-61.

16 Lothe RA, Peltomaki P, Meling GI, et al. Genomic instability in colorectal cancer: relationship to clinicopathological variables and family history. Cancer Res 1993;53:5849-52.

17 Thibodeau SN, Bren G, Schaid D. Microsatellite instability in cancer of the proximal colon. Science 1993;260:816-19. 
18 Liu B, Nicolaides NC, Markowitz S, et al. Mismatch repair gene defects in sporadic colorectal cancers with microsatellite instability. Nat Genet 1995;9:48-55.

19 Konishi M, Kikuchi-Yanoshita R, Tanaka K, et al. Molecular nature of colon tumours in hereditary nonpolyposis colon cancer, familial polyposis and sporadic colon cancer. Gastroenterology 1996;111:307-17.

20 Chung DC, Rustgi AK. DNA mismatch repair and cancer. Gastroenterology 1995;109:1685-99.

21 Chapuis PH, Dent OF, Fisher R, et al. A multivariate analysis of clinical and pathological variables in prognosis after resection of large bowel cancer. Br F Surg 1985;72:698702 .

22 Bjerkeset T, Morild I, Mork S, et al. Tumour characteristics in colorectal cancer and their relationship to treatment and prognosis. Dis Colon Rectum 1987;30:934-8.

23 Bennett MA, Kay EW, Mulcahy H, et al. Ras and p53 in the prediction of survival in Dukes' B colorectal cancer. 7 Clin prediction of survival in Duk Pathol 1995;48:M310-15.

24 Breukel C, Tops C, van Leeuwen C, et al. CA repeat polymorphism at the D5S82 locus, proximal to adenomapolymorphism at the D5S82 locus, proximal to adenoma-

25 Spirio L, Joslyn G, Nelson L, et al. A CA-repeat 30-70 kb downstream from the adenomatous polyposis coli (APC) gene. Nucleic Acids Res 1991;19:6348.

26 Hall JM, Friedman L, Guenther C, et al. Closing in on a breast cancer gene on chromosome 17q. Am f Hum Genet 1992;50:1235-42.

27 Jones MH, Nakamura Y. Detection of loss of heterozygosity at the human TP53 locus using a dinucleotide repeat polymorphism. Genes Chromosomes Cancer 1992;5:89-90.

28 Risinger JI, Boyd J. Dinucleotide repeat polymorphism in the human DCC gene at chromosome 18q21. Hum Mol Genet 1992;1:657.

29 Gyapay G, Morissette J, Vignal A, et al. The 1993-94 Genethon human genetic linkage map. Nat Genet 1994;7:322-5.

30 Kay EW, Mulcahy H, Barry-Walsh C, et al. Cytoplasmic c-erbB-2 protein expression correlates with survival in 455-61.
31 Kay E MD thesis. University of Dublin, 1996.

32 Ilyas M, Tomlinson IPM, Novelli MR, et al. Clinicopathological features and p53 expression in left-sided sporadic colorectal cancers with and without microsatellite instability. F Pathol 1996;179:370-5.

33 Dubik D, Shiu RPC. Transcriptional regulation of c-myc oncogene expression by estrogen in hormone responsive breast cancer cells. F Biol Chem 1988;263:12705-8.

34 Santos GF, Scott GK, Lee WFM, et al. Estrogen-induced post-transcriptional modulation of c-myc proto-oncogene expression in human breast cancer cells. F Biol Chem 1988; 263:9565-8.

35 Altman DG. Practical statistics for medical research. London: Chapman and Hall, 1991.

36 Kalbfleisch JD, Prentice RL. The statistical analysis of failure time data. New York: John Wiley and Sons, 1980.

37 Farber E. The step-by-step development of epithelial cancer: from phenotype to genotype. Adv Cancer Res 1996; 70:21-48

38 Toft NJ, Arends MJ. DNA mismatch repair and colorectal cancer. F Pathol 1998;185:123-9.

39 Markowitz S, Wang J, Myeroff L, et al. Inactivation of the type II TGF-beta receptor in colon cancer cells with microsatellite instability. Science 1995;68:1336-8.

40 Cymes K, Biden K, Simms L, et al. Microsatellite instability in the insulin-like growth factor II receptor gene in gastrointestinal tumours. Nat Genet 1996;14:255-7.

41 Cui $\mathrm{H}$, Horon IL, Ohlsson R, et al. Loss of imprinting in normal tissue of colorectal cancer patients with microsatellite instability. Nat Med 1998;4:1276-80.

$42 \mathrm{Kim} \mathrm{H}$, Jen J, Vogelstein B, et al. Clinical and pathological characteristics of sporadic colorectal carcinomas with DNA replication errors in microsatellite sequences. $A m \mathcal{F}$ Pathol 1994;145:148-56.

43 Watatani M, Yoshida T, Kuroda K, et al. Allelic loss of chromosome $17 \mathrm{p}$, mutation of the $\mathrm{p} 53$ gene and microsatellite instability in right- and left-sided colorectal cancer. Cancer 1996;77:1688-93. 